\title{
Communication and collaboration in subsidiaries in China - Chinese and expatriate accounts
}

\author{
Anne-Marie Søderberg* \\ Department of Intercultural Communication and Management, \\ Copenhagen Business School, \\ Porcelænshaven 18A, 2000 Frederiksberg, Denmark \\ E-mail:ams.ikl@cbs.dk \\ *Corresponding author

\section{Verner D. Worm} \\ Asia Research Center, \\ Copenhagen Business School Denmark, \\ Porcelænshaven 24, 2000 Frederiksberg, Denmark \\ E-mail: vw.int@cbs.dk
}

\begin{abstract}
The purpose of this article is to explore how Chinese and expatriate managers, working in subsidiaries of five MNCs, communicate and collaborate, what kind of cultural encounters they talk about and give prominence to in their accounts of critical incidents, how they reflect upon them/explain them, and how they cope with perceived similarities and differences to improve cross-cultural communication and collaboration within a global organisation.

Using an inductive qualitative methodology and thematic analysis, the study draws on in-depth narrative interviews with 29 expatriate and 39 Chinese managers and experts.

The specific value of this paper is that it explores a hitherto under-researched issue and provides insight into well-educated expatriate and Chinese managers' accounts of how they perceive themselves and others in a multicultural work context. In both groups, we find widely travelled, flexible and open-minded people, who are ready and have the capabilities to conduct cross-cultural leadership.
\end{abstract}

Keywords: cross-cultural communication and collaboration; intercultural effectiveness; cross-cultural learning processes; MNCs in China; expatriates; international management.

Reference to this paper should be made as follows: Søderberg, A-M. and Worm, V.D. (2011) 'Communication and collaboration in subsidiaries in China - Chinese and expatriate accounts', European J. Cross-Cultural Competence and Management, Vol. 2, No. 1, pp.54-76.

Biographical notes: Anne-Marie Søderberg is a Professor of Cross-Cultural Communication and Management at Copenhagen Business School. With a research focus on cultures, identity constructions, sensegiving and sensemaking, communication and learning processes, she has created a bridge between her educational background in the humanities and her present position as an international business scholar. She was the Director of the interdisciplinary research programme 'Cultural Intelligence as a Strategic Resource' (2008-2011). Based on extensive field studies in Danish MNCs and 
their Asian subsidiaries she co-authored with M.C. Gertsen and M. Zølner the book Global Collaboration. Intercultural Experiences and Learning to be published by Palgrave Macmillan in 2012.

Verner Worm is a Professor of Chinese Business and Development at Copenhagen Business School, Denmark. He holds a Master's degree in Sinology and a Bachelor's degree in Political Science from Copenhagen University. His primary research interest is Chinese indigenous management, international negotiations, international human resource management and cross-cultural management. He is a member of the research team in the 'Cultural Intelligence as a Strategic Resource' project. He has published in various academic journals including International Human Resource Management, International Journal of Conflict Management, Management International Review, and International Business Review. He serves at the editorial board of the Journal of Trust Research. He has taught cross-cultural management at various universities, such as Fudan University, Shanghai, China, Thunderbird Business School, Arizona, Bifrost University, Iceland, and international negotiations at Lingnan University, Guangzhou.

\section{Introduction}

An increasing number of foreign companies are involved in intercultural communication and cooperation in China in connection with the global exchange of labour and knowledge. This exchange takes place in various ways: through transnational mergers, acquisitions, and joint ventures; by moving production facilities closer to major markets; and by outsourcing administrative functions as well as R\&D activities to China, which has a highly skilled workforce, but comparatively lower wages than in the West.

China's economic development, with an average annual growth rate of $10 \%$ during the latest 30 years, has attracted almost all Western multinationals to set up production sites in China. Within the last 15 to 20 years, in particular after 1992, more than 600,000 foreign companies have been established in China (Hong Kong Trade and Development Council, 2009). In 2008, China received US $\$ 2$ billion in foreign direct investments, and even during the financial crises in 2010, it received US\$90 billion (Hong Kong Trade and Development Council, 2010).

More and more frequently, Chinese are hired to manage local employees in the subsidiaries of MNCs and through various managerial functions to accommodate company practices to the local surroundings. These local managers have to negotiate with their counterparts at company headquarters, as their task, to a great extent, is to 'translate' or adapt the overall corporate strategy to the local context in their function as boundary-spanners. However, expatriate managers and employees are still posted abroad in large numbers, which also makes interaction between expatriate and Chinese managers in subsidiaries an important research topic. China has more expatriates than any other country in the world, with more than 180,000 expatriates registered in 2007 (http://www.ezinearticles.com/?Growing-Number-of-Foreigners-in-China\&id=1081671). Today, both short and long term international assignments are part of the job, not just for management executives, but also for many engineers, financial controllers, sales and marketing people, and other groups of professionals. 
These recent developments make Chinese management of MNC's subsidiaries, as well as expatriates' communication, management, and cooperation with locals, important issues from a research point of view. The above mentioned trends in global business also stress the need for both expatriate and local managers to improve their mutual cultural understanding and develop intercultural competence - in other words, to raise their cultural intelligence (Thomas et al., 2008; Plum et al., 2008). But it also makes it a critical issue for HR management to select and develop those expatriate and local managers who have the capabilities and experiences that may improve cross-cultural leadership in a Chinese business environment.

It is not our purpose here to unfold or discuss the concept of cultural intelligence in any detail; suffice it to say that in general terms we understand it as "the capability of an individual to function and manage effectively in situations characterized by cultural diversity" [Ang and Van Dyne, (2008), p.3], and "the ability to make yourself understood and to establish a constructive partnership across cultural differences" [Plum et al., (2008), p.19]. Cultural intelligence encompasses cognitive, emotional, and behavioural dimensions:

- Knowledge about culture as a concept and about how specific cultures differ, as well as reflection on how culture affects one's own and others' behaviour and ways of thinking.

- Empathy and motivation to engage in cultural encounters and learn about situations characterised by cultural differences. This involves a certain degree of acceptance of the positive as well as the negative emotions involved, and a willingness to reflect upon them.

- Ability to act through verbal and non-verbal communication in order to establish a common ground for interaction with individuals perceived as culturally different.

We assume that the interactive linkage of the cognitive, emotional and behavioural dimensions will increase mutual understanding and collaboration across differences as well as stimulate what is often labelled 'cultural metacognition' (Thomas et al., 2008), that is reflection on intercultural experiences and strategies in order to achieve a more active monitoring of one's cognitive and affective states, learning activities, and intercultural communication and collaboration ability. Ultimately, the goal is to bridge and benefit from the cultural complexity of people with different nationalities, work areas, professional backgrounds, personalities, and organisational cultures (Plum et al., 2008). In this understanding of cultural intelligence, the concept transcends the focus on national value differences (the cross-national comparison perspective) and on clashes between national communication and negotiation styles (the intercultural interaction perspective), the two dominant paradigms in cross-cultural management research (Sackmann and Philips, 2004).

In this research paper, we will look closely at intercultural communication and collaboration among Danish expatriate managers and Chinese managers in various subsidiaries in Hong Kong and mainland China. Danish companies have not only established sales offices, but also invested in production sites and R\&D centres in China. In October 2008, 310 Danish companies were registered in China, and Danish investments in China amounted to 294 million USD (Trade Council of Denmark in China, 2008). 
We focus on communication and collaboration between expatriate managers and local Chinese managers in subsidiaries of five Danish MNCs in China. The research questions raised are: How do expatriate managers perceive their Chinese colleagues and subordinates and vice versa? What kinds of cultural encounters do expatriate and local Chinese managers talk about and give prominence to in their respective accounts of critical incidents? How do they reflect upon them, explain them, and how do they cope with them?

The article is organised as follows: First, we argue for the relevance of a qualitative approach to the study of intercultural communication and collaboration in a Chinese-Western business context to supplement quantitative survey studies of cultural values. Second, we introduce the research design and methodology used in the field study in China of subsidiaries of multinational companies of Danish origin. Third, we present the case companies involved. Fourth, we present analyses of interviews with Danish expatriates and Chinese managers, guided by the research questions listed above. Finally, we discuss our findings and their practical implications for companies.

\section{The research gap}

Selection, preparation and management of traditional long-term international assignees in multinational corporations have long been dominant themes in the IHRM literature (Stahl and Björkman, 2006; Rowley and Cooke, 2010). Much effort has been put into studying expatriation with the purpose of career development and managerial control of foreign subsidiaries. As many of the early foreign direct investments in China were in the form of joint ventures, there has consequently been a strong focus on Western MNCs' perspectives on control, management and knowledge transfer to China, both from a practitioner and a scholarly perspective. In the most widespread literature about human resource management in Western companies in China, traditional characteristics of Chinese human resource management have been compared with Western practices, which has sometimes resulted in a true polarisation, perhaps based on a limited understanding of the other side [for a discussion see, Whiteley et al. (2000) and Cooke, (2004)].

Comparative studies of traditional Chinese and Western values and work behaviours are plentiful, whereas studies of cross-cultural interaction in a contemporary Chinese business context are still rare. Westwood and Lok (2003) focussed on the following topics in cross-national comparisons: First, the embeddedness in relationships in China in contrast to the ego-centred view of self in Western cultures; Second, the strong moral obligation in collectivist cultures to contribute to the extended family's well-being through work and business activities in contrast to individualistic cultures where employees primarily care for themselves, and perhaps their partner and children; third, the Chinese pragmatism that makes people work hard when they see a reason to do so, for example, to achieve materialistic goals, in contrast to Westerners who tend to work hard in order to gain self-esteem and to fit into a specific metaphysical system (e.g., Protestant ethics). Huang and Van de Vliert (2003) also draw on comparative values perspectives between societies with individualism and collectivism respectively, and with small or high power distance, and in jobs with little or much opportunity to use skills and abilities across the divide between white and blue collar-workers. 
But globalisation processes, foreign direct investments, and the internet are linking contemporary China with the world and exposing Chinese people to foreign concepts, technologies, cultures, and life-styles (Child and Tse, 2001). The numbers of Chinese who have studied at foreign universities and business schools during 1977 to 2006 have exceeded 1 million. Also, Chinese institutions of higher learning are showing openness and willingness to change curriculum to adjust to the world outside China, and some of them are setting up joint programmes with foreign counterparts (Fang et al., 2008). Moreover, the political context in which Western companies are operating in China has radically changed during the last decade. Many MNCs have thus shifted investment strategies towards establishing wholly-owned subsidiaries in China (Vanhonacker, 1997). These changes also set a new research agenda.

Recent quantitative survey studies have found clear evidence for increasing convergence of HRM practices in local Chinese firms with those of European MNC units in China based on comparisons of findings from 1996 and 2006 (Björkman et al., 2008; Rowley and Cooke, 2010). How the qualitative changes in the investigated HRM processes (recruitment and selection, training, financial compensation, and performance appraisal) have taken place has not yet been described in detail in the literature.

Already Adler and Graham (1989) as well as Rao and Hashimoto (1996) have drawn attention to the international comparison fallacy and emphasised that cross-cultural interaction and collaboration differs significantly from interaction and collaboration within a specific national context. Books have been published with the purpose of making Westerners' communication with the Chinese more effective (for example, Gao et al., 1998) through better awareness of individualistic vs. collectivistic value orientations (Hofstede, 1980; Triandis et al., 1988; Trompenaars, 1993) and low- and high-context communication styles (Hall, 1976). But as stated by Gelfand et al. (2007) in their call for new approaches to cross-cultural OB-studies, "far less attention has been paid to the dynamics of culture in intercultural encounters, or what we would refer to as the cross-cultural interface". The scarcity of intercultural interaction and collaboration studies within the research fields of organisational behaviour and human resource management studies is still obvious, meaning that there is a lack of studies focusing in particular on intercultural interaction and collaboration. Given the increasing importance of communication and collaboration in multicultural business settings, there is a strong need for more empirically grounded studies that can provide a broader and deeper understanding of cross-cultural management and international human resource management practices through the use of a qualitative methodology that can give voice to participant experiences and perspectives derived from daily practice.

In accordance with the recommendations in Gelfand et al. (2007), we are studying the dynamics of cultural interfaces in global companies instead of comparing national values as if people and organisations were still unaffected by globalisation processes. Moreover, we do not only look at perceived differences in values and management practices, but also at similarities. It is important to find out on which common ground communication and collaboration may be improved and intercultural trust can be built in the Chinese-Western business contexts where we have conducted our field studies. With our field work in subsidiaries of MNCs in China, we aim to contribute to filling the research gap. In this specific research paper, we offer a description of the evolution of cross-cultural collaboration between Western expatriate and Chinese managers based on a dialogue about perceived cultural differences and similarities, and reflections on how to find a common ground guided by shared goals. 
Literature on cross-cultural management in a Chinese business context (for example, Huang and Van de Vliert, 2003) has often focused on the view of Chinese culture as being relatively stable and homogeneous, a complicating issue in the effectiveness of foreign business in China. In contrast to this understanding of culture and cultural barriers, we see cultures as negotiated and socially constructed, and we build our work on an understanding that values, beliefs, and behaviours are subject to changes when economies develop and cultures interact with each other (Faure and Fang, 2008). Studies of cultural differences in values and work behaviours may help in reaching a better understanding of some of the challenges managers face in cross-cultural encounters. But achieving effective communication and collaboration in culturally complex business contexts also requires that organisational actors agree on points of similarity and focus on shared goals (Plum et al., 2008). We claim that some previous studies of cross-cultural management in China have overemphasised cultural differences between nationalities and toned down other important cultural differences between generations, professions, companies, and industries. Furthermore, they have abstracted from the fact that a certain convergence between Western and Chinese business worlds has already taken place, especially during the last decade, as documented by, for example, Björkman et al. (2008). Hence, due to globalisation processes, Western expatriates and Chinese managers in MNCs are coming closer to each other in the ways they think and act, at least in the workplace. There might still be differences between expatriates and Chinese managers in cultural values and preferences that have to be taken into consideration in intercultural communication and collaboration. But in this paper, we would, nevertheless, shift from a one-sided focus on seemingly insurmountable cultural barriers to analysis of individual accounts from both expatriate and Chinese managers about how they have tried to cope with perceived differences, learned to bridge across them, and find common ground and thus developed a more culturally intelligent behaviour.

\section{Research design and methodology}

The empirical material analysed in the following consists of in-depth interviews with expatriates and Chinese managers. The interviews were conducted during a three week field trip to China in September 2009 where the authors visited subsidiaries of five multinational companies of Danish origin in Hong Kong, Xiamen, Shanghai, Suzhou, Beijing, and Tianjin. ${ }^{1}$ The transcribed interview excerpts presented in the following are only a small sample of a much larger corpus consisting of 56 interviews. In 2009, we interviewed expatriate top managers (15) and middle managers (7) as well as international graduates/trainees with a Western background (7). Moreover, we conducted interviews with Chinese top managers (16) and middle managers (22) as well as one international graduate with a Chinese background.

Many of the Danish expatriates had been studying and travelling abroad, and had experiences from other international assignments before they were employed in a subsidiary of a Danish MNC in China. We also met expatriates with a Chinese family background, who grew up in Denmark but speak Chinese fluently, and therefore must be considered bicultural (Thomas et al., 2010) rather than either Danish or Chinese. According to our interviewees, quite many Chinese managers, both younger and middle-aged, have deliberately chosen to work in multinational companies in China instead of in state-owned businesses. Almost all of the Chinese we interviewed had been 
travelling outside China, if not for other purposes then in order to receive training at the headquarters or in other subsidiaries. Some Chinese managers had also studied at foreign universities and business schools before they started their career in business; others were offered MBA studies abroad along with their job. Furthermore, the majority of both the expatriates and the Chinese managers and supervisors had worked for other multinational companies before we met them in their current positions. We want to emphasise this information about the interviewees' educational background, travel, and job experiences because their exposure to foreigners and foreign cultures, as well as their command of one or more foreign languages (almost all of them spoke fairly good English, which was the corporate language in all case companies), make them differ significantly from the image often received in existing literature on international human resource management. The dominant perspective has been that most expatriates are not experienced in dealing with foreigners, and that local managers likewise are considered as average citizens with little knowledge about the world outside their own national borders (see for example Dowling et al., 2008). Recent publications show, though, that many expatriates have extensive international experience from previous assignments and from working with other nationalities in project teams, etc. Second, MNCs often target and manage to recruit highly talented local people who may have previous international experience (Mäkelä et al., 2010).

Most of the interviews, we conducted with expatriates as well as Chinese managers lasted between one hour and one and a half hours, and everything was recorded in order to be transcribed subsequently. Participation in the study was voluntary, and the interviewees were assured anonymity and confidentiality. The interviews were semi-structured - the interviewees were asked about a number of different topics, including their personal and educational backgrounds and motivations for accepting an expatriate position and/or a position in a subsidiary of an MNC. Insofar as it was possible, a narrative approach (Søderberg, 2006; Gertsen and Søderberg, 2011a) was chosen, which means that we encouraged the interviewees to tell stories about their experiences of intercultural encounters, examples of situations they found particularly challenging, coping strategies they had developed, learning points they had achieved, etc.

The authors, who conducted the interviews themselves, are both Danes, and they have a background in cross-cultural communication and management studies, and in sinology and Chinese business studies respectively. Interviews with Danish expatriates were conducted in Danish and have subsequently been translated into English, whereas interviews with Chinese and other foreign top managers were conducted in English, which is the lingua franca used in the case companies. Ten Chinese project managers and supervisors were interviewed in smaller groups of two to four persons. Those interviews were conducted in Mandarin by one of the authors, and the excerpts used in this paper have subsequently been translated to English. We expected that it would be easier for those people to express themselves in a more varied and unrestrained way in their native language, because in their daily interactions at the workplace they did not speak English to the same extent as the Chinese top and middle managers (Welch and Piekkari, 2006).

We are well aware of the fact that Danish expatriates may tend to construct an ad hoc national community with the Danish interviewers whereas the Chinese, even when interviewed in Mandarin, may have more reservations towards scholars from the country where the company headquarters is located. Despite the fact that we are independent scholars, not employed at headquarters, nor necessarily representing the Danish companies' perspectives on the subsidiary and its local managers and employees, our 
nationality might still have had some impact on the social relations between us as interviewers and the interviewees of both Danish and Chinese origin. They were aware that headquarters representatives facilitated our access to the managing director and HR director in the Chinese subsidiary, who then made arrangements with interviewees and set up the interview schedules.

Compared with existing literature on doing field work in China, we seem to have found an easy way to gain access through our previous studies at the headquarters of the MNCs whose Chinese subsidiaries we visited. Vallaster (2000) emphasises the problem of establishing trust in China, which we only felt if and when we explicitly asked Chinese interviewees to talk about their experiences with and perceptions of expatriates in the subsidiary in question. Eckhardt (2004) stresses the importance of understanding Chinese culture when interviewing in China, which of course is extremely important, especially if your interviewees seldom have been exposed to foreigners. As mentioned earlier, one of the authors is a sinologist by profession and has lived in China for eight years and visited China regularly during the last 30 years. It gave us a privileged access to the Chinese interviewees, no matter if they were interviewed in English or in Mandarin.

After transcription of the interviews, we analysed them thematically. We followed the process of pattern coding (Miles and Huberman, 1994), but were careful in identifying the emergence of a particular pattern. When a particular pattern seemed to be emerging, we sought to assess if there was any more evidence that supported that particular pattern (Guba, 1981). Regarding the final case, we are not claiming that it is representative. The case was chosen because it shows how people from different cultures can transform a conflicting situation to a cooperative one that can even develop into a learning case for others in similar situations.

\section{Description of the case companies}

All five multinational companies find themselves at different stages in the processes of globalisation, and are thus facing new types of cultural challenges and an overall increase in the frequency of complex cultural encounters. As we see it, these encounters include not merely national aspects of culture, but also, for instance, professional and organisational dimensions, i.e., the concept of culture that informs the research project and its study of the global workplace is multifaceted and dynamic (Sackmann and Philips, 2004).

The complex cultural environments in which the companies find themselves today are in flux and continually subject to negotiation between management, employees, customers, and external stakeholders (Tung et al., 2008). Culture is thus something strategising organisational actors do and use in specific contexts in attempts to make sense of themselves, understand the complex organisational reality, negotiate power relations, and gradually change or develop their cultural identities (cf. Jarzabkowski, 2004). In this process, they draw upon several cultural discourses (regional, national, professional, organisational, etc.). From our perspective, culture is thus not only seen as shared knowledge and behaviour, but rather as a discursive process of sense-making that can be polyphonic in itself, and sometimes contested and disharmonious. In this research context, the notion of cultural intelligence is interesting - both to us as researchers and to the employees in the companies. 
All five case companies have both production and sales activities in China, and they have plans to expand their operations in the near future. They are organised with local headquarters in one of the major cities (Hong Kong, Shanghai and Beijing) and production facilities placed outside these cities in industrial development zones.

Most of the case companies are reducing the number of expatriates and thus delegating more responsibility to well-educated and experienced Chinese managers (Leung et al., 2009). However, some of the case companies are still bringing in more expatriates, not only because they want to expand their activities in China, but also because they want to integrate the China operations more strongly into the global organisation. It can be done through more extensive collaboration in global teams in various staff functions (for example sales and marketing, corporate communications, HR, IT and Finance), as well as through virtual collaboration between R\&D units located in different countries (Ling et al., 2007).

Communication and collaboration across borders is accompanied by efforts to standardise at a global scale and thus link the organisational units and change the MNC into a sustainable global network with shared values and common guidelines for 'winning behaviors' (Gertsen and Søderberg, 2011b). Abolition of local habits (e.g., red envelopes with additional salary that Chinese staff used to receive around the Chinese New Year) in order to align with global standards and accommodate to the current financial crises may create friction between headquarters and the subsidiary, as well as between expatriates and local staff (Masgoret and Ward, 2006). Introduction of new procedures, guided by a recently launched 'code of conduct' for the global organisation, may also challenge senior managers, expatriates, and locals who have - for years - managed the Chinese subsidiaries more as local sales companies than as units in a more transparent and globally interconnected organisation (Fang et al., 2008).

\section{How do expatriate managers perceive their Chinese colleagues and subordinates?}

Expatriate managers' perceptions of Chinese managers are, in many cases, a reflection of the number of years the expatriates have spent in China. Expatriates with many years of international assignments in China will obviously know the local environment better than newcomers who tend to think and act more ethnocentrically.

A first issue for many expatriates is to realise that there are different ways to establish expatriate-local relationships in a subsidiary in China, and that the prevalent dominant-dominated relationship between expatriates and local people is an institutional arrangement ( $\mathrm{Li}$ and Kleiner, 2001). This relationship can be played out in different directions through a company's more deliberate choice among one of four acculturation strategies: assimilation, integration, separation, and marginalisation (Berry, 2008). One of our interviewees, an expatriate senior manager, displayed humbleness towards making the Chinese staff assimilate to his standards:

"You can try to change 12.000 Chinese so that they work like you, or you will have to change yourself and start working like the Chinese. You have to accept to start leading by directives so that the communication becomes more clear and simple." 
On the other hand, the statement above also displays an understanding of Chinese subordinates as somebody who needs to be treated nearly like children, that is to be supervised, urged, and ordered to live up to Western management standards.

Another dominant perception among expatriates is that Chinese managers and employees - at least in the beginning of their careers - avoid risk taking, and, as a function of this, do not take any individual initiatives like Western managers tend to do. An expatriate manager comments on that as a challenge to be met:
"We need to change their behavior around risk taking and individual initiative. Here are some real shortcomings. I am working consciously on making them less risk aversive. I think I understand the reason. I don't know how I would think and behave if I was employed in a company in Denmark where the senior managers were Chinese. It would really be strange. But I get the feeling that they pay a certain respect to Westerners, so they don't really challenge us."

Many expatriates also had difficulties understanding why the Chinese subordinates paid this respect to foreigners and displayed modesty for potential lack of skills and competencies. Perhaps the Chinese feared losing their jobs during a period with turbulent societal changes and a world-wide economic crisis, which also has resulted in some cut-backs in the five case companies' Chinese subsidiaries. In general, Chinese managers and employees treated all Western expatriates with much respect, and this behaviour was especially difficult to accommodate to for those expatriates who were still fairly young and not very experienced, who had no command of the Chinese language and only a modest understanding of the Chinese market and Chinese customers, yet were much better paid and had many benefits and privileges compared to their Chinese colleagues. A younger managing director, among our expatriate interviewees, expressed a concern that the MNC should pursue a stronger localisation strategy so that the highly qualified local staff would not lose motivation to work toward being promoted and making a full career within the global company:

\footnotetext{
"I want a local manager to succeed me. It is my ambition - right now I have a deputy managing director who is highly competent. I also think we will undermine the local succession planning if we continue sending young guys to China and train them in managing some "innocent" Chinese. There are indeed enough competent Chinese managers. Everybody in my management team has higher educational levels than I have obtained. They have studied in the US and UK and other places around the world, and they know both the Western and the Chinese cultures very well."
}

Somewhat in contrast to the respectful behaviour that the Chinese displayed at the workplace in other situations, several expatriates mentioned they were disappointed with what they perceived as lack of loyalty, when Chinese employees, without further notice, left the company as soon as they received a better paying job or a job with better career opportunities.

\section{How do Chinese managers perceive Western expatriates?}

According to cross-cultural communication and management literature, Chinese are supposed to relate more strongly to other people than Westerners (Redding, 1990; Trompenaars, 1993). But when Chinese interviewees were asked about how they perceive their expatriate colleagues and superiors, they tend to avoid commenting on 
them, both as a group and as individuals. A reason for that could be that we are Danes and thus represent the dominant and economically powerful group in the organisation, as we already mentioned in our methodological self-reflections. Why should Chinese interviewees immediately trust us, even though we try to convince them that we are independent researchers? This methodological issue must be taken into consideration when reading the Chinese accounts of how they perceived Western expatriates and their communication and management style.

Several Chinese managers expressed the opinion that in general, expatriates today know more about China and its traditions than previous generations of expatriates. Almost all the Chinese staff in managerial positions had been at the headquarters in Denmark, which also made it easier for them to cooperate with expatriates and probably also contributed to the convergence in management practices documented in other studies of European MNCs in China (Björkman et al., 2008). At the same time, Chinese staff members mentioned, however, that the Chinese seem to learn more about Western societies, culture and management than the Westerners learn about China. In order to make up for expatriates' ignorance about Chinese culture and management practices, a point consistently emphasised by Chinese interviewees as an important issue, the Chinese interviewees suggested that someone from, or living in, Mainland China should give new expatriates an introduction to China. It was obvious that the Chinese staff did not like the China-specific training that some of the expatriates in the subsidiaries had received as part of their pre-departure training by overseas Chinese or so-called China experts among the Western culture trainers hired by the headquarters' HR department. This disaffection may have been because the culture-specific introduction was superficial, with its focus on adaptive behaviour (e.g., the exchange of business cards); perhaps it may also have been because the training conveyed cultural stereotypes and myths that did not match up with the dynamic development of values and management practices in China.

One of the last questions, we asked in our interviews was about whether the Chinese thought that there were too many expatriates in the subsidiary. Most Chinese avoided answering this question directly, and the Chinese focus groups we had set up would remain silent for a long time, then smile, meaning that they really thought this was the case. Nevertheless, some well-educated Chinese managers voiced the opinion that they had already touched the 'glass ceiling', and they realised they did not have many opportunities to make a full career in the MNC in question. However, other Chinese interviewees had succeeded in getting senior manager positions and becoming members of a global management team within their field, whereas some had been offered MBA studies in order to pursue a further career within the MNC. This demonstrates that some localisation strategies were being implemented at the personnel level at the same time as the multinational companies were trying to disseminate a corporate culture and a corporate code of conduct in order to link the many units within the global organisation.

As many Chinese employees spend a lot of energy on navigating their relations to a new expatriate boss, the argument traditionally put forth by the Chinese side has been that the longer the expatriates stayed in China, the better (Wang et al., 2000). Therefore, we were somewhat surprised that some Chinese interviewees mentioned that the expatriates should not become too Chinese because the Chinese really wanted to learn from them about Western management. It was one of the reasons they had decided to work in an MNC, not in a Chinese private business or a state owned company. From a Chinese point of view, this motivation points in the direction of short-term assignments 
as the preferred mode of expatriation. This issue is obviously somewhat related to the specific job, but also to the capability of the expatriate to build trust.

The insecurity felt by the Chinese managers seems to be higher than most expatriates realise, which makes trust a central issue. One of our Chinese interviewees mentioned that it takes at least half a year for him before he trusts a foreigner. This view points in the direction of long-term assignments as the preferred mode because it requires long-time cooperation to build trust. A younger Chinese senior manager told us this illuminating story:
"The first time I was dealing with Westerners, I have to say that I was shocked by the cultural differences. A delegation from a European company wanted to acquire a Chinese company and asked a lot of questions about who their competitors were, what was the product's position in the market, etc. But the local managers felt a lot of pressure due to all these questions and also some mistrust. The Chinese did not want to speak frankly about that feeling with the foreigners, so they just kept silent. Because they kept silent, the Western side thought that the Chinese company did not know its competitors and that the managers were stupid, and when foreigners think that the Chinese are stupid, they will, of course, be met with some very strong reactions from the Chinese side."

As can be seen from the above quotation, a lot of mistrust was created in this specific communication process due to the European delegation's very direct and straightforward question mode; this could have been avoided if the foreign partners had been trained in more indirect communication and made more aware of their own and other communication styles. More fundamentally, it is a question of cultural intelligence in the sense that the Europeans should be aware of the Chinese reactions and be able to reflect on the consequences of their own approach. However, differences in work-related attitudes and practices can also be overcome if there is a high level of trust among expatriates and locals, and, moreover, if they focus on their shared organisational identity:

"I have a Chinese colleague who puts this in a very good way when she talks to her employees. She says: 'In the office we are all X-company employees. At home you can be as Chinese as you want, but when you come here, you have to behave in a certain way to meet the ... kind of corporate requirements."'

When Chinese interviewees with many years work experience in MNCs commented on the Western expatriates' way of managing, they often described them as quite systematic, very straightforward in their communication and very careful in explaining procedures in detail as compared to the Chinese tradition, which comprises much more indirectness, but also leaves something to the employees' own flexible decision-making. Furthermore, the Chinese mentioned that they would normally not try to persuade a colleague with another opinion, but just accept that they had different opinions. Discussion is not a natural element in a hierarchical society, which is obviously difficult to understand for expatriates who typically try - often in vain - to encourage discussion among staff to solidify decision making processes.

One of the few critical issues that Chinese interviewees mentioned was the expatriates' perception of personal relationships:

"If an expatriate has put a group of Chinese together, he thinks that he has the relevant relationships set up so he will get good feedback, but for the Chinese, this group is very artificial because he put those people together. And maybe I 
will only give him feedback if I have established a relation with him. Only if I see him as a friend or somebody I can trust.”

In the example above, the difference between expatriates and Chinese is that the Chinese do not necessarily see a work group as a network; networks are always between particular individuals (Chen, 2004).

\section{A Danish and a Chinese account of mutual learning through cross-cultural collaboration}

In the next section, we will not only focus on how the interacting parties perceive cultural differences and similarities, but also how they try to overcome them and find common ground. In the existing literature on expatriate-local relations, there has been more focus on foreign expatriates who have been superiors to Chinese middle managers (for example Gertsen and Søderberg, 2010; Li and Kleiner, 2001; Worm, 1997), and less on relations between expatriates with a Chinese superior.

Based on two in-depth interviews, we have chosen to tell a story about how an expatriate manager from Denmark and his Chinese superior, the CEO of Mainland China, initially experienced severe conflicts ${ }^{2}$. In trying to cope with their perceived differences, they discovered a way to improve their collaboration by giving due respect to their respective status and different competencies.

Peter Hansen $^{3}$ is an expatriate manager in his mid-thirties. He has travelled extensively since he left high school, including in East Asia, and he has lived for a while in multicultural, metropolitan London. He emphasises his travel experiences in his self-presentation as something that has made him more open-minded and flexible towards living and working under new conditions. After he graduated from a business school in 1998, he was hired by the MNC, where he made a meteoric rise in his career, first at headquarters, with the responsibility for strategy development of European operations, and, since 2007, in China. The company offered him some cross-cultural training, which he benefited from when, as strategy director, he was responsible for the MNC's business development in Mainland China for one and a half years. Hansen also speaks some Mandarin and assigns importance to it:

"It is also important in order to signal to them that you have been here for a longer period, and you take them seriously and have interest in them. And it also shows them that you are a bright guy, able to start learning a new language and picking up new information."

At the time when the interview took place, he had been working as a managing director of the Shanghai office for about a year.

His superior is a middle-aged Chinese, Tony Chang ${ }^{4}$, who has studied in the UK and worked for this MNC for the last 20 years. He started in the company as sales manager and has gradually climbed up the career ladder; for the last four years, he has been CEO for Mainland China. Even though Chang is travelling frequently among the MNC's 19 production sites in China, as well as to meetings at the headquarters in Denmark, he is also based in Shanghai. This means that the Danish managing director and the Chinese CEO have to work closely together.

By virtue of his long career in the MNC in question, Chang describes himself as 'half a Dane' in contrast to those Chinese employees who have never been travelling and 
working outside China. Nevertheless, the initial collaboration phase with Hansen has been characterised by many conflicts and many misunderstandings, some of them probably due to different views of work and work-life-balance, different approaches to management and people, and differences in communication style and the use of communication media (for example e-mails).

In the interviews we conducted with Hansen and Chang, they both stress that, at long last, they have come to understand each other's ways of thinking and acting to an extent that the conflicts have diminished. Hansen acknowledges that Chang has been his mentor and that he has taught him a lot, not only about market conditions, but also about social relationships in China, including face issues. Hansen emphasises that in the public sphere, he always acknowledges Chang as his superior and his mentor. But, Hansen thinks that he could - at least indirectly - also support Chang in dealing more professionally with strategic issues.

Hansen had been trained at the headquarters in strategic planning and business development, and he has experienced how the Danish CEO delegated responsibility to him and other subordinates, who would then take control of the specific tasks. When he tried to introduce this management style in China by assigning more general objectives without explicitly stipulating what should be done at a certain time and how, his Chinese colleagues would tend to wait for more detailed instructions, but without asking directly for them. Hansen explained "then Friday afternoon arrived, and the Chinese had done nothing at all, but they would defend themselves by saying that the task they had been given by me was not sufficiently specified, and they missed a daily follow-up". Hansen had difficulties implementing what he called 'directive management', but he realised that he could not immediately change his subordinates' behaviour. Therefore, he expressed willingness to adapt to Chinese work habits to a certain extent, but he also had the ambition to gradually teach his subordinates how to change their routines and reorient themselves towards more strategic thinking and planning:
"I gave them some templates and said: "Now we will start defining what to measure, and for that purpose we need a format to indicate what we want to achieve in 2008 and in 2009 . We need to define who the members of this project group are, and we start by writing down the format, and then let's meet again late in the afternoon.' You need to be sure that they fill in the information themselves, that they take ownership of the task, that they gain an understanding of what the project is about. You must start that way with all your employees, no matter which fancy titles they have. You must acknowledge that they have never learned to work that way, and if you want them to work more independently, you will have to teach it to them. And here you must take the point of departure from the way they are used to do things, then gradually you can raise the bar."

Chang is accustomed to micro-management of his Chinese subordinates with daily appraisals. Moreover, he looks upon the company as a family, where he, as the CEO, is the father (pater familias) for the Chinese subordinates and cares for their well-being, also outside work:

"Quite many Western people look into China and say: 'there are no human rights.' But if you look into the very small organisations in China, maybe their human rights are far, far greater than those that Danish people perform in their daily lives. And my caring for the staff is not limited to business hours." 
He mentions that he often spends time with subordinates after working hours and that he recently visited a Chinese middle manager who was hospitalised, a paternalistic management style in accordance with traditional Chinese management practices (Redding, 1990; Fahr and Cheng, 2000; Cheng et al., 2004; Chen and Kao, 2009).

Chang also takes a father's responsibilities for the expatriates. Sometimes he gets upset about young expatriates if they arrive totally unprepared, act ethnocentrically and show no patience, but just want things to be done their way. He looks upon the young ambitious managing director, Peter Hansen, as if he were a son of the CEO at the Danish headquarters, which of course also complicates his relation to him as CEO to a subordinate manager.

Chang stresses that he wants to take care of Hansen and educate him to work professionally in the Chinese business world. He summarises a didactic story he told to Hansen about receiving a Ferrari as a gift from the Danish corporate CEO and driving that expensive car first in a well-known Danish environment and then in China where the 'traffic rules' are different:
"I said: 'Son, I bought you a Ferrari, but son be careful, because now you've come to China - and your father is now Tony Chang, and even if there's a red light be careful, because some cars will not stop behind you but rather crash into your car. When you come to the zebra crossing, don't stop your car because in China no one does that.' (..) 'Now the whole issue is that your boss, your father, wants you to have a safe drive and come home safely, so this behavior is a kind of care more than simply interruptions and intervention.",

Hansen talks explicitly about his previous conflicts with Chang who has given him two nicknames: the 'golden boy' due to his close relations to the Danish CEO of the MNC who furthered his quick international career, and the 'turbo engine' due to his energetic, but somewhat impatient way of managing things. Chang confirms that they have had some conflicts, but he does not want to go into details, perhaps in order not to make Hansen lose face in front of us.

One issue that Hansen initially found exasperating was Chang's comments on and interference with what he considered issues much too small for a CEO to bother about:

\begin{abstract}
"But Tony Chang went poking his nose into everything ... he was very concerned because I hardly had any paper left on my desk in the office, and he was anxious that the Chinese would think that I was not doing a bloody thing, so I had to put some piles of paper on the desk... On the other hand, I also received a letter from him saying that he was quite sure that pupils in Danish elementary schools were taught to place their chairs under the desks. And he mailed to everybody in the Shanghai office that somebody had forgotten a pizza box on the copy machine. In the beginning, I just thought that it was ridiculous, but little by little you understand that of course this is micromanagement, but it is also the Chinese way to use tiny examples as symbols of some essentials. A left pizza box tells something about the company's concern for the environment and about paying respect to colleagues. Placing the chair under the desk when leaving the office is important if you, as manager, want other people to act disciplined. And paper on the manager's desk tells your subordinates about being hard-working and committed."
\end{abstract}

But the quote above also displays how Hansen changes from perceiving Chang's instructions as 'simply pathetic' to reaching an understanding that the Chinese CEO communicates rules and norms through small stories and symbolic actions and wants to influence his subordinates through role modelling. 
Another thing that triggered Hansen was Chang's reactions to his way of quickly communicating his own solutions to a problem by e-mails to all employees in the office, and thereby sometimes threatening the face of his superior and undermining his authority as CEO. This was the case if and when Chang had made another decision and tried to get employees' support to his own approach through numerous consultations face-to-face. Hansen tells:
"At the headquarters in Denmark, it is easy for a powerful boss to say: 'Okay, if I am an idiot I am so happy that I am surrounded by smarter people.' Then we all will laugh and go on. But it does not work in China. It has to be the eldest and most experienced who proposes the best solution. If a junior puts forward a better idea, it will create a problem for the senior, and it means that the idea will be crushed at birth no matter how good it is. When I realized that, I started writing e-mails in a draft format and then just checked up with colleagues: 'Did Tony Chang mention this project?' And with some bigger issues, I just tell Chang that I plan to reply to this specific mail, and if he has not already mailed, I will take an initiative. The problem is that you are sometimes much too quick, thinking 'I can fix this or that in 3 minutes, and I know very well how it must be done.' And then you forget about the cultural dimension: Who is in charge of replying to this request? Who has the power to solve this problem? I wonder if Tony Chang is already about to solve this problem the Chinese way by talking to everybody in this office and telling them about his approach. If that is the case, I am going to create a problem instead of solving one."

Another issue that caused some trouble was different perspectives on work vs. family life. Whereas work-life balance is an issue being launched as part of corporate culture and corporate social responsibility in this $\mathrm{MNC}$, as well as in many other Western MNCs, there is not a strict divide between life at the workplace and family life for the middle-aged Chinese CEO. Chang tells us that his mother, wife and daughter visited him at his office when he, as a younger manager, worked on Sundays. It is a recurrent theme in the interview with him that Chinese are ready to sacrifice. This attitude has caused him problems with many Western expatriates whom he has tried to tell that developing a new business in China is so demanding that they should forget about keeping a work-life balance:
"This is a business we are going to build! Not like in Copenhagen where you have a hundred and fifty years experience and ... the company is well established, so you can go home from headquarters on Fridays at 3:30. In this market, no way! That is the terms, and if you don't understand it, you had better leave! In China, you know you have to sacrifice. So I lost all kinds of communication with my daughter until she entered university."

In consequence of this understanding of work and business as first priority, the Chinese CEO often called the expatriate managing director, who has a spouse and two small children, at home. In the long run, it created some conflicts. Hansen tells us that Chang once called him a Sunday morning because he wanted to discuss a meeting the forthcoming Wednesday. Hansen got so upset and asked why they could not discuss that in the office the day after. After that, Hansen simply hung up the phone, which of course was a severe face-threatening act towards a superior. In this situation, Hansen ran the risk of being sent back to Denmark, but when it did not happen, Hansen thought that it had to do with the fact that the Danish CEO had called Chang before he was sent to China and said that he should teach Hansen how to do business in China, teach him how the Chinese 
market was functioning and ensure that he became well-integrated into Chinese culture since they at headquarters still had a limited understanding of China. This was a very positive, face-affirming act towards Chang, and Hansen's strong relation to the Danish CEO probably also gave him more free room to learn to accommodate to Chinese conditions than other expatriates would have been offered.

Hansen appreciated the Danish CEO's introduction of him as a sort of apprentice because it appealed to the father-role Chang normally played towards his Chinese employees, and Hansen realised that it was important for him, as well as for headquarters, to display humbleness towards those who were experienced with working in a Chinese business environment. He was well aware that he and other well-paid and privileged expatriates were evaluated on a daily basis by the local Chinese managers and employees, who would think about what the expatriates could contribute to the business when they did not speak the Chinese language fluently and did not know the Chinese market or Chinese culture (Li and Kleiner, 2001; Lin, 1989; Pye, 1982; Worm, 1997).

It is obvious from the interviews that the Danish MD and the Chinese CEO did not understand each other very well in the beginning. In Table 1, we have summarised their initial approaches to communication and management.

Table 1 Initial differences between the expatriate managing director and the Chinese CEO

\begin{tabular}{|c|c|}
\hline Peter Hansen & Tony Chang \\
\hline Younger, in his ' 30 s & Middle-aged \\
\hline Managing director of a site in China & CEO of Greater China \\
\hline 11 years in the $\mathrm{MNC}$ & 20 years in the $\mathrm{MNC}$ \\
\hline Internationally oriented and widely travelled. & $\begin{array}{l}\text { Internationally oriented, calls himself 'half a } \\
\text { Dane' }\end{array}$ \\
\hline Speaks English fluently and some Mandarin & Speaks English fluently \\
\hline $\begin{array}{l}\text { Direct communication that may threaten the } \\
\text { face of his superior and subordinates. }\end{array}$ & $\begin{array}{l}\text { More indirect communication related to } \\
\text { events. }\end{array}$ \\
\hline Delegates responsibility to subordinates. & $\begin{array}{l}\text { Directive management and supervision of } \\
\text { subordinates. }\end{array}$ \\
\hline \multirow{2}{*}{$\begin{array}{l}\text { Looks upon the subsidiary as a unit to be } \\
\text { integrated in the global company through } \\
\text { strategic thinking. }\end{array}$} & $\begin{array}{l}\text { Looks upon the } \mathrm{MNC} \text { as a network of personal } \\
\text { relations. }\end{array}$ \\
\hline & $\begin{array}{l}\text { Looks upon the subsidiary as a family, where } \\
\text { he as CEO acts as a father to the subordinates } \\
\text { and as PH's mentor. }\end{array}$ \\
\hline Cooperative capabilities important. & Seniority and experiences important. \\
\hline \multicolumn{2}{|l|}{$\begin{array}{l}\text { Characterises himself as a mediator and } \\
\text { negotiator. }\end{array}$} \\
\hline Tries to obtain a certain work-life balance. & $\begin{array}{l}\text { Sacrifices his family life in order to develop } \\
\text { business in an emergent market. }\end{array}$ \\
\hline
\end{tabular}


West China, which was too culturally distant. The job as managing director in Shanghai provides opportunities for him to give attention to cultural differences in communication and management practices, and he feels commitment to overcome at least some of them in order to build intercultural trust in relation to his superior (Li, 2011). Moreover, Hansen characterises himself as a mediator and a negotiator and refers to his experiences as brother number two in a family with three children. He also emphasises that he has often drawn on these experiences and personal capacities in his professional life.

In order to deescalate the frequent conflicts, the two managers started talking about why they spontaneously reacted as they did in certain conflict situations. Through dialogue about their different cultural backgrounds and experiences grew a mutual deeper respect, and according to Hansen, they really started working as a management team after a tough first year. This case shows that it is possible to negotiate a 'modus vivendi' where perceived differences do not create insurmountable barriers for cooperation, and where similarities also count: The two men in charge of the management of operations in China were both ambitious leaders with a strong identification with the MNC and its strategic goals to make the company a big global player in the world's largest market for its specific products.

During our interviews, it became clear that they felt they had learned something from each other while maintaining their cultural distinctions; in other words, they had practiced an integration strategy (Berry, 2008). Hansen learned a lot about the way the Chinese market was operated as well as about how Chinese develop social relationships to the benefit of business. Hansen's strong networks with executive managers at the MNC's headquarters had been beneficial for Chang, and he has also drawn on Hansen's strategic competencies. Chang gradually changed his management style and started making more long-term strategy plans, and, according to Hansen, he thereby improved his status at the Danish headquarters:
"Tony Chang has really changed his working style, just as I have changed mine. He works much more structured and has been quick to adapt to approaches and procedures I brought into the office...Chinese are good at copying if they find something that functions in a smarter way. Now he is also making milestone planning, he writes very well structured e-mails, and launches follow-up-systems - we both get something out of the collaboration."

But there were still areas where the Danish expatriate manager tried to keep to his lifestyle and stick to his norms. Even though he was a hard-working man like Chang, he tried to separate work and family life, and it was little by little accepted by Chang. Hansen wraps up:

\footnotetext{
"The first year in China was really tough. There were many points of frictionespecially when you bring with you spouse and small children, and when your Chinese boss thinks that the most important key performance indicator is to work seven days a week, and the more you are traveling in Mainland China, the better. Chang has absolutely no understanding of what it means to be a father in a Danish family. In China, the father is simply the breadwinner, and then you will employ somebody to take care of the kids. It means that in the initial phase, you are marking your territory - you cannot win all the battles - you must be ready to yield - and you must also send some signals that you are willing to learn and adapt. On the other hand, you must also be very conscious about what you want to stand firm on. It is the only way to gain respect from the counterpart."
} 


\section{Conclusions}

Many cross-cultural management studies have focused on differences between Chinese and Western values (Redding, 1990; Fahr and Cheng, 2000; Cheng et al., 2004; Chen and Kao, 2009). The specific value of this research paper is that it explores a hitherto under-researched issue and provides insight into well-educated expatriate and Chinese managers' accounts of how they perceive themselves and others in a multicultural work context, and how they try to cope with perceived similarities and differences to improve cross-cultural communication and collaboration within a global organisation.

Based on narrative interviews conducted in autumn 2009 in the Chinese subsidiaries of five MNCs, we have revealed that the dominant perspective on expatriates and local managers as people living in separate worlds and holding significantly different values and opinions must be revised. We found in both groups, well-educated and widely travelled, flexible and open-minded people who had the capacities to communicate and collaborate in culturally complex business contexts.

In in-depth interviews with 39 Chinese managers and experts in the five companies, we got the impression that an increasing number of Chinese managers, engineers, technicians - and even workers - have opted to join non-Chinese companies on a permanent basis, be it in Western, Japanese, Korean, or Taiwanese companies. If they leave one foreign company, they are normally headhunted by other foreign companies, or they themselves apply for jobs in them. One reason for this trend might be that a majority of foreign companies in China are located in so-called Industrial Development Zones that provide numerous job opportunities in a geographically limited area; another reason might be that the working conditions and salaries in foreign companies are better than in most Chinese state-owned companies.

Many of the Chinese managers and experts we met already had job experience in other MNCs; someone has even worked for MNCs for the last 20 years. Some Chinese mentioned that they had deliberately chosen to apply for jobs in an MNC just after they graduated from university to get better training, more exposure, and experience with working for bigger brands. Moreover, they were attracted by the ways things were structured and planned, as well as by the corporate cultures and codes of conduct launched (and practiced?) in the MNCs. It means that collaboration between Westerners and Chinese in a business context cannot just be viewed as encounters between people with well-defined national identities and with cultural values and behavioural patterns deeply rooted in Western and Chinese traditions. This statement applies most strongly to the younger generation of Chinese experts and managers who often have also studied abroad.

We do not claim that "the world is flat" (Friedman, 2006), and what we experience today in a globalising business world is simply a convergence between Western and Chinese values and behavioural patterns. But, we propose that experiences with studying and working abroad and the existence of bicultural identities (Thomas et al., 2010) should be taken more into account when framing and understanding the conditions for intercultural communication and collaboration in subsidiaries in contemporary China.

In the case studies we have conducted, Chinese and expatriate managers have told us stories about difficult cultural encounters, and how they reflected upon them and gradually learned to cope with them. We assume that cultural intelligence may be a strategic resource and a competitive advantage at workplaces. We have met many people, 
both Chinese and expatriate managers, who - based on their own accounts of critical incidents and reflections upon them - seemed experienced with and well-informed about both Chinese and Western cultures, and, moreover, empathetic and open-minded and thus ready to try to find ways to bridge perceived cultural differences, rather than either insisting on their own norms and values or adapting to others.

In the introduction to this paper, we defined cultural intelligence as a competence developed through dialogue, not something to be measured solely through self-reports. The case we have presented involving a Western expatriate managing director and his superior, a Chinese CEO, matches this understanding in the sense that it gives voice to both interlocutors, their self-perception as well as their perception of the other, their reflections on critical incidents, and their accounts of ways they have learned to cope with perceived differences and similarities in order to improve collaboration.

Some of our interviewees, both expatriates and Chinese, seem to have not only the cognitive and emotional capacities for cross-cultural leadership, but also the ability to practice it in relation to people with different nationalities and professions, working in different business units, and belonging to different generations (Gian and Waldman, 2007). Nevertheless, we would suggest that development of cultural intelligence is given higher priority in companies, both at an individual and an organisational level. We are convinced that the findings and theoretical perspectives presented here should assist multinational companies in their selection and development of culturally intelligent expatriate and local managers through global talent management programmes as well as through on-site mentoring and coaching activities.

Our case studies in China have made it possible to collect empirical material that is rich and diverse. We give voice not only to expatriate managers' perspectives and opinions, but also to Chinese managers who are seldom heard in a Western research context. But our approach is, of course, also subject to a variety of limitations. One limitation is that the empirical material primarily consists of company documents and qualitative interviews. The expatriate and Chinese managers' retrospective interpretations of events and specific communication and collaboration processes are based on the interviewees' selective memories and their more or less deliberate plot constructions, which may both serve the function of making sense of critical events for the individual narrator and to impress the audience, in this case the two interviewers. In the subsidiaries in China, we have not had any access to participant observation of meetings, negotiations, or other kinds of daily collaboration practices that might have challenged and/or improved the validity of our findings.

One way to test the heuristic value of our findings will be through seminars and workshops with practitioners in the multinational case companies. We hope that through such activities we can initiate discussions with relevant organisational actors about new approaches to culture training and global talent management (see also, Gertsen and Søderberg, 2010). In this way we can, at the same time, generate new knowledge about the companies' current practices and thus supplement our qualitative interviews.

\section{References}

Adler, N.J. and Graham, J.L. (1989) 'Cross-cultural interaction: the international comparison fallacy?', Journal of International Business Studies, Vol. 20, pp.515-537. 
Ang, S. and Van Dyne, L. (2008) 'Conceptualization of cultural intelligence: definition, distinctiveness, and nomological network', in Ang, S. and Van Dyne, L. (Eds.): Handbook of Cultural Intelligence: Theory, Measurement and Applications, pp.3-15, M.E. Sharpe, Armonk, NY.

Berry, J.W. (2008) 'Globalisation and acculturation', International Journal of Intercultural Relations, Vol. 32, pp.328-336.

Björkman, I., Smale, A., Sumelius, J., Suutari, V. and Lu, Y. (2008) 'Changes in institutional context and MNC operations in China: subsidiary HRM practices in 1996-2006', International Business Review, Vol. 17, No. 2, pp.146-158.

Chen, H. and Kao, H. (2009) 'Chinese paternalistic leadership and non-Chinese subordinates', Psychological Health, Vol. 20, pp.2533-2546.

Chen, M. (2004) Asian Management Systems, 2nd ed., Thomson, Singapore.

Cheng, B., Chou, L., Wu, T., Huang, M. and Fahr, J. (2004) 'Paternalistic leadership and subordinate responses: establishing a leadership model in Chinese organizations', Asian Journal of Social Psychology, Vol. 7, pp.89-117.

Child, J. and Tse, D. (2001) 'China's transition and its implication for international business', Journal of International Business Studies, Vol. 32, No. 1, pp.5-25.

Cooke, F. (2004) 'Foreign firms in China: modeling HRM in a toy manufacturing corporation', Human Resource Management Journal, Vol. 14, No. 3, pp.31-42.

Dowling, P., Festing, M. and Engle, A. (2008) International Human Resource Management, 5th ed., Thomson, Australia.

Eckhardt, G.M. (2004) 'The role of culture in conducting trustworthy and credible qualitative business research in China', in Marschan-Piekkari, R. and Welch, C. (Eds.): Handbook of Qualitative Research Methods for International Business, pp.402-420, Edward Elgar, Cheltenham.

Fahr, J. and Cheng, B. (2000) 'A cultural analysis of paternalistic management', in Li, J., Tsui, A. and Weldon, E. (Eds.): Management and Organizations in the Chinese Context, pp.84-128, MacMillan Press, London.

Fang, T., Worm, V. and Tung, R. (2008) 'Changing success and failure factors in business negotiation with PRC', International Business Review, Vol. 17, No. 2, pp.159-169.

Fang, T., Zhao, S. and Worm, V. (2008) 'Editorial - the changing Chinese culture and business behavior', International Business Review, Vol. 17, No. 2, pp.141-145.

Faure, G.O. and Fang, T. (2008) 'Chinese values - keeping up with paradoxes', International Business Review, Vol. 17, No. 2, pp.194-207.

Friedman, T.L. (2006) The World is Flat - A Brief History of the Twenty-First Century, Farrar, Strauss and Ciroux, New York.

Gao, G., Kao, K. and Ting-Toomey, S. (1998) Communicating Effectively with the Chinese, Sage Publications, Thousand Oaks.

Gelfand, M.J., Erez, M. and Aycan, Z. (2007) 'Cross-cultural organizational behavior', Annual Review of Psychology, Vol. 58, pp.479-514.

Gertsen, M.C. and Søderberg, A.M. (2010) 'Expatriate stories about cultural encounters - a narrative approach to cultural learning processes in multinational companies', Scandinavian Journal of Management, Vol. 26, pp.248-257.

Gertsen, M.C. and Søderberg, A.M. (2011a) 'Intercultural collaboration stories: on narrative inquiry and analysis as tools for research in international business', Journal of International Business Studies, Vol. 42, No. 6, pp.765-786.

Gertsen, M.C. and Søderberg, A.M. (2011b) 'Together we are stronger' - a case study of Carlsberg's concept 'Winning Behaviours' in the wake of a series of international acquisitions', in Ławniczak, R. (Ed.): Challenges for Communication Management and Public Relations in International Mergers and Acquisitions, pp.87-109, CEED Research, Poznan. 
Gian, C. and Waldman, D.A. (2007) 'Cross cultural comparison of the importance of leadership traits for effective low-level and high-level leaders: Australia and China', International Journal of Cross Cultural Management, Vol. 7, No. 1, pp.47-60.

Guba, E. (1981) 'Criteria for judging the trustworthiness of naturalistic inquiries', Educational Communication and Technology Journal, Vol. 29, pp.75-92.

Hall, E.T. (1976) Beyond Culture, Anchor, New York.

Hofstede, G. (1980) Culture's Consequences: International Differences in Work Related Values, Sage Publications, Beverly Hills CA.

Hong Kong Trade and Development Council (2009) available at http://info.hktdc.com/main/china.htm (accessed on 15 December 2009).

Hong Kong Trade and Development Council (2010) http://info.hktdc.com/main/china.htm. (accessed on 12 May 2010).

Huang, X. and Van de Vliert, E. (2003) 'Comparing work behaviors across cultures', International Journal of Cross Cultural Management, Vol. 3, No. 2, pp.167-182.

Jarzabkowski, P. (2004) 'Strategy as practice: recursiveness, adaptation, and practices-in-use', Organization Studies, Vol. 25, No. 1, pp.529-560.

Leung, K., Zhu, Y. and Ge, C. (2009) 'Compensation disparity between locals and expatriates: moderating the effects of perceived injustice in foreign multinationals in China', Journal of World Business, Vol. 44, No. 1, pp.85-93.

Li, P.P. (2011) 'The rigor-relevance for engaged scholarship: new frame and new agenda for trust research and beyond', Journal of Trust Research, Vol. 1, No. 1, pp.1-21.

Li, L. and Kleiner, B.H. (2001) 'Expatriate - local relationship and organizational effectiveness: a study of multinational companies in China', Management Research News, Vol. 24, Nos. 3/4, pp.49-56.

Lin, Y. (1989) My Country and my People, (First published in 1936), Heinemann Asia, Singapore.

Ling, F.Y.Y., Ang, A.M.H. and Lim, S.S.Y. (2007) 'Encounters between foreigners and Chinese: perception and management of cultural differences', Engineering, Construction and Architectural Management, Vol. 14, No. 6, pp.501-518.

Mäkelä, K., Björkman, I. and Ehrnrooth, M. (2010) 'How do MNCs establish their talent pools? Influences on individuals' likelihood of being labeled as talent', Journal of World Business, Vol. 45, No. 2, pp.134-142.

Masgoret, A. and Ward, C. (2006) 'Cultural learning approach to acculturation', in Sam, D.L. and Berry, J.W. (Eds.): The Cambridge Handbook of Acculturation Psychology, pp.58-77, Cambridge University Press, Cambridge.

Miles, M. and Huberman, A. (1994) Qualitative Data Analysis, Sage Publications, Thousand Oaks, CA.

Plum, E., Achen, B. Dræby, I. and Jensen, I. (2008) CI - Cultural Intelligence - The Art of Leading Cultural Complexity, Middlesex University Press, London.

Pye, L. (1982) Chinese Commercial Negotiating Style, Rand Corporation, Santa Monica.

Rao, A. and Hashimoto, K. (1996) 'Intercultural influence: a study of Japanese expatriate managers in Canada', Journal of International Business Studies, Vol. 27, No. 3, pp.443-466.

Redding. G. (1990) The Spirit of Chinese Capitalism, de Gruyter, New York.

Rowley, C. and Cooke, F. (2010) The Changing Face of Management in China, Routledge, London.

Sackmann, S. and Phillips, M. (2004) 'Contextual influence on culture research - shifting assumptions for work place realities', International Journal of Cross Cultural Management, Vol. 4, No. 3, pp.370-390.

Søderberg, A-M. (2006) 'Narrative interviewing and narrative analysis in a study of a cross-border merger', Management International Review, Vol. 46, No. 4, pp.397-416. 
Stahl, G. and Björkman, I. (2006) 'International human resource management: an introduction to the field', in Stahl, G. and Björkman, I. (Eds.): Handbook of Research in International Human Resource Management, pp.1-11, Edward Elgar, Cheltenham.

Thomas, D., Stahl, G., Ravlin, E., Poelmans, S., Pekerti, A., Maznevski, M., Lazarova, M.B., Elron, E., Ekelund, B.Z., Cerdin, J.L., Brislin, R., Aycan, Z. and Au, K. (2008) 'Cultural intelligence: domain and assessment', International Journal of Cross-Cultural Management, Vol. 8, No. 2, pp.123-143.

Thomas, D.C., Brannen, M.Y. and Garcia, D. (2010) 'Bicultural individuals and intercultural effectiveness', European Journal of Cross-Cultural Competence and Management, Vol. 1, No. 4, pp.315-333.

Trade Council of Denmark in China (2008) The List of Danish Companies in China (accessed on 21 December 2009).

Triandis, H., Brislin, R. and Hui, H. (1988) 'Cross-cultural training across the individualism-collectivism divide', International Journal of Intercultural Relations, Vol. 12, No. 3, pp.269-289.

Trompenaars, F. (1993) Riding the Waves of Culture: Understanding Cultural Diversity in Business, Economist Books, London.

Tung, R., Worm, V. and Fang, T. (2008) 'Sino-Western business negotiation revisited - 30 years after China's open door policy', Organizational Dynamics, Vol. 37, No. 1, pp.60-74.

Vallaster, C. (2000) 'Conducting field research in Asia: fundamental differences as compared to western societies', Culture \& Psychology, Vol. 6, pp.461-476.

Vanhonacker, V. (1997) 'Entering China: an unconventional approach', Harvard Business Review, March-April, pp.130-141.

Wang, P., Zhi, Y. and Tan, K. (2000) 'Control and performance in Sino-Foreign equity joint ventures', in Li, J., Tsui, A. and Weldon, E. (Eds.): Management and Organizations in the Chinese Context, pp.131-156, MacMillan Press, London.

Welch, C. and Piekkari, R. (2006) 'Crossing language boundaries: qualitative interviewing in international business', Management International Review, Vol. 46, No. 4, pp.417-437.

Westwood, R. and Lok, P. (2003) 'The meaning of work in Chinese context: a comparative study', International Journal of Cross Cultural Management, Vol. 3, No. 2, pp.139-166.

Whiteley, A., Cheung, S. and Quan, Z. (2000) Human Resource Strategies in China, World Scientific, Singapore.

Worm, V. (1997) Vikings and Mandarins, Copenhagen Business School Press, Copenhagen.

\section{Notes}

1 This article draws upon data from the research project 'Cultural Intelligence as a Strategic Resource' (2008-2011). The project is funded by the Danish Council for Strategic Research and has been carried out by a team of researchers at Copenhagen Business School in collaboration with five MNCs headquartered in Denmark and operating, among other locations, in the emergent markets in Asia. The empirical material has been collected by Lisbeth Clausen, Liv Egholm Feldt, Martine Cardel Gertsen, Michael Jacobsen, Anne-Marie Søderberg, Verner Worm, and Mette Zølner. The interviews analysed in this article have been conducted by Anne-Marie Søderberg and Verner Worm. The authors alone are responsible for the analysis, reflections, and perspectives presented in this article.

2 These two interviews have also been used in Gertsen and Søderberg (2011a), with a focus on narrative inquiry and narrative analysis as qualitative methods in international business.

3 The company name, the names of individuals, and some of the locations have been changed in order to protect the interviewees' anonymity.

4 The names of individuals are fictitious in order to protect their anonymity. 